\title{
Novel Isothermal Membrane Distillation with Acidic Collector for Selective and Energy-Efficient Recovery of Ammonia from Urine
}

\author{
Stephanie N. McCartney, Natalie A. Williams, Chanhee Boo, Xi Chen, and Ngai Yin Yip*
}

Cite This: ACS Sustainable Chem. Eng. 2020, 8, 7324-7334

Read Online

ABSTRACT: The high concentration of ammonia in sourceseparated urine offers propitious opportunities for $\mathrm{N}$ recovery. Membrane distillation (MD) can recover volatile ammonia from hydrolyzed urine, but conventional operation suffers from the simultaneous permeation of water vapor that results in poor selectivity for ammonia transport and high energy demand. Here, we present a novel operation of $\mathrm{MD}$-isothermal membrane distillation with acidic collector (IMD-AC) - to overcome the limitations of conventional MD. The innovative isothermal operation, i.e., same feed and collector temperatures, effectively suppressed water vapor permeation while maintaining ammonia

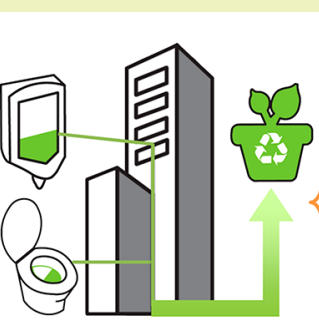

Source-separated urine

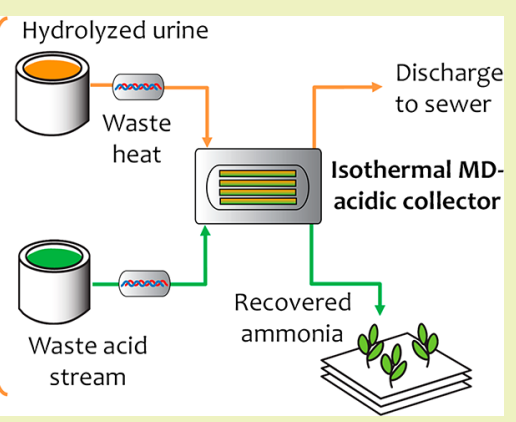
vapor flux and, thus, significantly improved selectivity for ammonia transport. The acidic collector further enhanced ammonia vapor flux by an average of $46.5 \%$ compared to using a deionized water collector. Against a total ammoniacal nitrogen concentration gradient, i.e., uphill transport, ammonia recovery of $\approx 60 \%$ was attained, highlighting the prospect of the technology for high-yield recovery. Critically, IMD-AC achieved approximately $95 \%$ savings in vaporization energy consumption relative to conventional MD by practically eliminating the evaporation of water. The resultant energy requirement of $\approx 2.2 \mathrm{kWh} / \mathrm{kg}-\mathrm{N}$ is less than the Haber-Bosch process for $\mathrm{N}$ fixation and $\mathrm{N}$ removal by nitrificationdenitrification (8.9-19.3 and 2.3-6.5 kWh/kg-N, respectively). This study shows the promising potential of IMD-AC for the selective and energy-efficient recovery of ammonia from source-separated urine.

KEYWORDS: Resource recovery, Circular economy, Waste utilization, Low-grade heat, Hydrophobic microporous membrane, Wastewater infrastructure

\section{INTRODUCTION}

Management of nitrogen, an essential nutrient for life, has been recognized by the National Academy of Engineers as one of the Grand Challenges. ${ }^{1}$ The current practices of $\mathrm{N}$ production, consumption, and disposal are unsustainable. ${ }^{2}$ Anthropogenic $\mathrm{N}$ emissions to the aquatic ecosystem cause eutrophication, harmful algal blooms (HABs), and hypoxic dead zones in surface waters and marine coastal areas. ${ }^{3-5}$ In addition to the ecological and environmental devastation, cyanobacteria and algal toxins from HABs pose public health threats. ${ }^{6,7}$ Reducing $\mathrm{N}$ discharge from point sources, such as wastewater treatment plant (WWTP) effluent, has been identified as a vital nutrient contaminant management strategy. ${ }^{8}$ However, most WWTPs are not equipped with tertiary treatment, i.e., dedicated stage for nutrient removal. Even when advanced treatment is present to lower $\mathrm{N}$ concentrations, considerable energy and chemical costs are required. ${ }^{9}$ Conventional $\mathrm{N}$ removal by nitrificationdenitrification at WWTPs demands $2.3-6.5 \mathrm{kWh} / \mathrm{kg}-\mathrm{N} .^{10-13}$

Global food security is dependent on ammonia, the bioavailable form of $\mathrm{N}$ and a principal component of fertilizer. At the same time $\mathrm{N}$ is emitted to the environment, nitrogen is fixed from the atmosphere through the energy-intensive
Haber-Bosch process, requiring 8.9-19.3 kWh/kg-N, and accounts for $\approx 1-2 \%$ of the world's energy use. ${ }^{14-16}$ In other words, ammonia is produced at huge energy cost and further expenditures are incurred downstream, for the removal of excess nutrients from our wastewater to prevent environmental and public health problems. The biogeochemical flow of nitrogen is, hence, flagged as exceeding the safe operating space for humanity, posing high risks under the planetary boundaries framework. ${ }^{2}$ The current linear economy approach is clearly untenable, and a new paradigm for sustainable nitrogen management is urgently needed. ${ }^{17-19}$

Instead, nitrogen in anthropogenic wastewaters can be recovered to promote a more sensible circular economy model. Nitrogen recovery efforts at WWTPs are presently constrained by pollution risks, low yields, and/or high costs. Land

Received: January 23, 2020

Revised: April 17, 2020

Published: April 22, 2020 
applications of biosolids, i.e., treated sewage sludge, is the prevailing practice; ${ }^{20,21}$ however, the method risks contamination from toxic heavy metals, pharmaceuticals, personal care products, and pathogens. ${ }^{20-26}$ Approaches that separate $\mathrm{N}$ from WWTP wastewater for reuse were explored, ${ }^{27-32}$ but progress is thwarted by low recovery yields and high energy and chemical expenses of these techniques. ${ }^{33}$ For instance, ammonia recovery from wastewater by precipitation of phosphate-based minerals is typically limited to only $\approx 5-$ $15 \%$ yield, ${ }^{30,31}$ and energy demand of $\mathrm{N}$ recovery methods range from approximately 5 to $18 \mathrm{kWh}$ per kg of N. ${ }^{10,30,34,35}$ An underlying reason for the difficulties in the implemention of practical $\mathrm{N}$ harvesting at WWTPs is the inherently low nutrient concentration of the flows.

A more forward-looking approach that is better aligned with the principles of Green Engineering is the recovery of $\mathrm{N}$ from source-separated urine, ${ }^{36-39}$ which contains $\approx 80 \%$ of the nitrogen from human excretions. ${ }^{40-42}$ Because urine isolated at-source is not diluted by flush water and gray water, the $\mathrm{N}$ concentration is two orders of magnitude greater than municipal wastewater, a significantly more favorable condition for separation and capture. ${ }^{37-39,41,43,44}$ Various approaches to extract ammonia from urine have been explored, including vacuum distillation, stripping-adsorption, mineral precipitation, ion-exchange, and electrochemical methods. ${ }^{45-51}$ However, most efforts thus far have generally fallen short of costcompetitiveness with the Haber-Bosch process because the approaches were prohibitively capital-intensive and/or demanded high operating energy and chemical cost. ${ }^{10,39,46,52,53}$

Membrane distillation (MD), an emergent technology that utilizes low-temperature heat to drive the permeation of volatile compounds across a hydrophobic microporous membrane, ${ }^{54-56}$ can take advantage of the intrinsic high volatility of ammonia. ${ }^{57-59}$ Most MD studies focused on desalination, i.e., separation of water from saline feed streams, ${ }^{54-56,60}$ but the potential of the technique for ammonia separation and recovery was recently investigated. ${ }^{57-59,61-80}$ However, harvesting ammonia from source-separated urine using $\mathrm{MD}$ is hampered by the undiscerning transport of all volatile components, including water. The unavoidable permeation of $\mathrm{H}_{2} \mathrm{O}$ along with $\mathrm{NH}_{3}$ is undesirable because of the additional energy demand to evaporate water and dilution of the product stream. ${ }^{61,62}$

In this study, we demonstrate a novel operation of direct contact membrane distillation, termed isothermal membrane distillation with acidic collector (IMD-AC), to overcome the limitations of conventional MD in the separation and recovery of ammonia from simulated urine. The working principles of IMD-AC are first presented, and the features differentiating the technique from conventional MD are highlighted. Vapor fluxes of ammonia and water in conventional and isothermal MD are compared, and the selectivity for $\mathrm{NH}_{3}$ permeation over $\mathrm{H}_{2} \mathrm{O}$ is analyzed. The influence of an acidic solution as the collector stream on $\mathrm{NH}_{3(\mathrm{~g})}$ transport is examined. Next, the study evaluated the effects of temperature on IMD-AC performance. The heat energy consumed to vaporize water and ammonia is then quantified to assess the energy savings of IMD-AC over conventional MD. The implications of IMD-AC for ammonia recovery from source-separated urine are discussed, and the potential utilization for other environmental applications are identified.

\section{ISOTHERMAL MEMBRANE DISTILLATION WITH ACIDIC COLLECTOR}

Limitations of Conventional Membrane Distillation for Ammonia Recovery. Membrane distillation (MD) is a separation process where volatile compounds are driven across a hydrophobic microporous membrane while nonvolatile components are retained in the feed stream. Working principles of $\mathrm{MD}$ are detailed in literature $e^{54,55}$ and are briefly explained here with specific focus on ammonia recovery. In the conventional operation of direct contact $\mathrm{MD}$, the feed stream is at a higher temperature than the permeate, or sweep/ collector, stream, i.e., $T_{\mathrm{F}}>T_{\mathrm{C}}$ (subscripts $\mathrm{F}$ and $\mathrm{C}$ denote feed and collector streams, respectively). Because partial vapor pressure of volatile component $i, P_{i}$, is exponentially dependent on the solution temperature, as described by the ClausiusClapeyron relation, ${ }^{81}$ the temperature difference sets up a vapor pressure gradient between the feed and collector sides at the solution-membrane interfaces. The transmembrane vapor pressure difference, $P_{\mathrm{F}, i}-P_{\mathrm{C}, i}$ (subscripts $\mathrm{F}$ and $\mathrm{C}$ denote feed and collector sides, respectively), is the driving force for the compound to volatilize from the feed solution, permeate across the membrane, and eventually condense in the collector stream. Vapor flux of component $i, J_{i}$, is described by eq $1:^{55}$

$$
J_{i}=L_{i}\left(P_{\mathrm{F}, i}-P_{\mathrm{C}, i}\right)
$$

where membrane vapor permeability coefficient, $L_{i}$, characterizes the transport of compound $i$ per unit driving force and is dependent on the vapor molecule, membrane structural properties and membrane chemistry, feed and collector compositions as well as operating conditions such as temperature. $^{54-56}$

Although MD is primarily employed for water recovery from saline feed streams, i.e., desalination, ${ }^{54,55,82}$ the technique can also be used to separate volatile compounds, including ammonia, from aqueous solutions. ${ }^{57-59,75,83}$ However, using conventional membrane distillation (CMD) for ammonia separation also unavoidably vaporizes water, resulting in simultaneous permeation of water vapor together with $\mathrm{NH}_{3(\mathrm{~g})}$ flux (Figure 1A). The indiscriminate transport of water limits the effectiveness of conventional $\mathrm{MD}$ in applications where selective permeation of one volatile component is desired. For $\mathrm{NH}_{3}$ recovery from urine, the incidental water vapor flux, $J_{\mathrm{W}}$, unfavorably dilutes the ammonia concentration of the product (i.e., collector stream effluent). ${ }^{84}$ More importantly, because evaporating water is very energy intensive (enthalpy of vaporization $\approx 630 \mathrm{kWh} /$ $\mathrm{m}^{3}$ ), the concomitant $J_{\mathrm{W}}$ would detrimentally raise the thermal energy input required for the overall process. Note that column distillation is similarly encumbered by the disadvantage of inevitable water evaporation.

Working Principles of Isothermal Membrane Distillation with Acidic Collector. To overcome the limitations of conventional $\mathrm{MD}$ for separating volatile compounds from aqueous solutions, specifically the recovery of ammonia from hydrolyzed urine, we introduce isothermal membrane distillation (IMD), where the feed and collector streams are at the same temperature, i.e., $T_{\mathrm{F}}=T_{\mathrm{C}}$. Note that the main form of nitrogen in fresh, i.e., unhydrolyzed urine, is urea, $\mathrm{CO}\left(\mathrm{NH}_{2}\right)_{2}$, which has a very low Henry's law constant; urea undergoes hydrolysis by urease enzymes naturally present in urine to form bicarbonate and volatile ammonia, eventually yielding hydrolyzed urine, ${ }^{41}$ i.e., $\mathrm{MD}$ is not applicable to fresh urine for $\mathrm{N}$ 

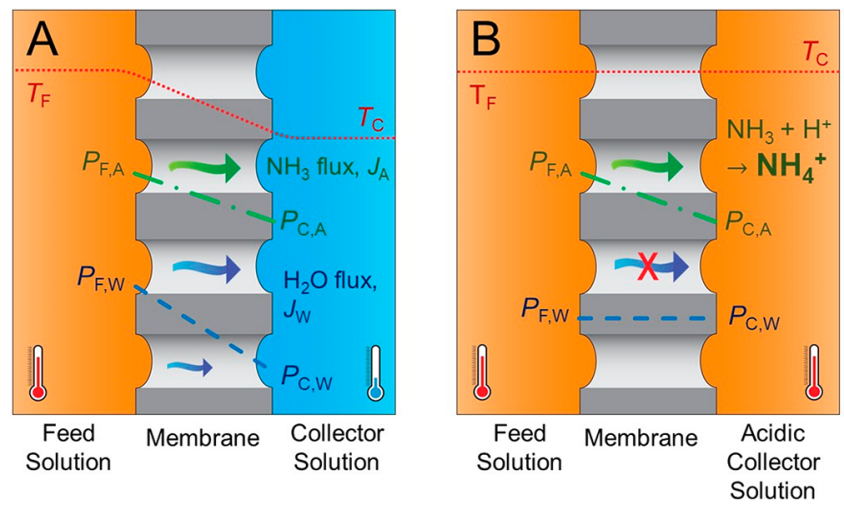

Figure 1. Temperature and vapor pressure profiles for (A) conventional and (B) isothermal MD with acidic collector. The temperature difference between the solution-membrane interfaces in $\mathrm{CMD}$ establishes a water vapor pressure gradient from feed to collector side, thus driving water vapor flux, $J_{\mathrm{W}}$ (blue arrow). Whereas the driving force for $J_{\mathrm{W}}$ is effectively zero in IMD, because the identical solution temperatures set up a constant water vapor pressure across the membrane. As $\mathrm{NH}_{3(\mathrm{~g})}$ vapor pressure is linearly proportional to ammonia concentration in the aqueous solution (Henry's law), both CMD and IMD exhibit a gradient for ammonia vapor pressure from feed to collector side, thus driving $\mathrm{NH}_{3(\mathrm{~g})}$ permeation, $J_{\mathrm{A}}$ (green arrows). Permeated $\mathrm{NH}_{3}$ that solubilizes in the acidic collector solution associates with $\mathrm{H}^{+}$to form nonvolatile $\mathrm{NH}_{4}^{+}$.

recovery. The equivalent temperature on both sides effectively eliminates the partial $\mathrm{H}_{2} \mathrm{O}$ vapor pressure gradient, thus ceasing the driving force for water vapor transport. Partial vapor pressure is linearly proportional to concentration of the volatile component in aqueous solution, $c_{\mathrm{i}}$, as governed by Henry's and Raoult's laws (determination of vapor pressure of solutions of different composition and temperature is detailed in the Supporting Information). ${ }^{85}$ Therefore, for ammonia (and other volatile compounds), a driving force for permeation from feed to collector subsists for $c_{\mathrm{F}, \mathrm{A}}>c_{\mathrm{C}, \mathrm{A}}$ (subscript $\mathrm{A}$ indicates ammonia, $\mathrm{NH}_{3}$ ), even when temperature profile across the membrane is flat, i.e., unlike conventional $\mathrm{MD}$ operation (Figure 1B). Critically, by curbing $J_{\mathrm{W}}$, IMD avoids the heat energy input required to evaporate water that is unpreventable in conventional $\mathrm{MD}$.

In the isothermal operation of $\mathrm{MD}$, ammonia vapor permeates from feed to collector side when there is an $\mathrm{NH}_{3 \text { (aq) }}$ concentration gradient between the aqueous solutions, i.e., $c_{\mathrm{F}, \mathrm{A}}-c_{\mathrm{C}, \mathrm{A}}>0$. But as more ammonia is separated from the feed stream and captured in the collector stream, $\mathcal{C}_{\mathrm{F}, \mathrm{A}}$ decreases while $c_{C, A}$ increases, thus gradually diminishing the driving force for ammonia vapor flux, $J_{\mathrm{A}}$ (eq 1). Eventually ammonia recovery ceases as $\mathrm{NH}_{3(\mathrm{aq})}$ concentration of the collector approaches the feed solution. To address this constraint, a second feature of acidic collector (AC) is incorporated to promote the speciation of volatile ammonia, $\mathrm{NH}_{3}$, in the collector stream to ionic ammonium, $\mathrm{NH}_{4}^{+}$, which is nonvolatile. ${ }^{57,58,61-74} \mathrm{~A}$ weak acid in the collector solution maintains a low $\mathrm{pH}$ that is below the $\mathrm{p} K_{\mathrm{A}}$ of ammonia (between 9.4 and 8.3 for solution temperatures of 20-60 $\left.{ }^{\circ} \mathrm{C}\right),{ }^{86}$ effectively converting all $\mathrm{NH}_{3}$ that has permeated over to the collector to $\mathrm{NH}_{4}^{+}$(Figure $\mathrm{S} 1$ of Supporting Information). Therefore, $\mathrm{NH}_{3(\mathrm{aq})}$ concentration of the collector stream is practically negligible, i.e., $c_{\mathrm{C}, \mathrm{A}} \approx 0$, even though the total ammoniacal nitrogen, $\mathrm{NH}_{3}+\mathrm{NH}_{4}{ }^{+}$, concen- tration increases. Therefore, a positive driving force for $J_{\mathrm{A}}$ is always sustained, i.e., $P_{\mathrm{F}, \mathrm{A}}-P_{\mathrm{C}, \mathrm{A}}>0$. Overall, the isothermal and acidic collector features of IMD-AC can, respectively, suppress the undesirable permeation of water vapor, thus reducing the heat energy required to vaporize water, and eliminate the partial vapor pressure of ammonia in the collector solution, to maximize the driving force for $\mathrm{NH}_{3}$ flux and enable high recovery yields.

\section{EXPERIMENTAL SECTION}

Materials and Chemicals. Commercial microporous hydrophobic polyvinylidene fluoride (PVDF) membrane of $0.22 \mu \mathrm{m}$ poresize, GVHP14250, was acquired from MilliporeSigma (Burlington, MA) and utilized for all membrane distillation experiments. The simulated urine feed solution comprised $250 \mathrm{mM}$ ammonium hydroxide and $250 \mathrm{mM}$ ammonium bicarbonate in deionized (DI) water from a Milli-Q ultrapure water purification system (MilliporeSigma) to mimic the total ammoniacal concentration and $\mathrm{pH}$ of hydrolyzed urine. ${ }^{37-39,41,42}$ DI water was used for the collector stream in nonacidic MD experiments. To prepare the acidic collector solution, acetic acid was diluted in DI water. All chemicals utilized in the experiments were analytical grade and were purchased from ThermoFisher Scientific (Waltham, MA).

Ammonia Separation and Recovery Experiments. Ammonia and water vapor fluxes were evaluated in four different operating modes: conventional membrane distillation with DI water collector (CMD-DI), conventional MD with acidic collector (CMD-AC), isothermal MD with DI water collector (IMD-DI), and isothermal $\mathrm{MD}$ with acidic collector (IMD-AC), i.e., the parameters assessed are collector stream composition (DI water or acid) and conventional versus isothermal operation. Simulated hydrolyzed urine was consistently utilized as the feed solution. For CMD-AC and IMDAC operations, $100 \mathrm{mM}$ acetic acid was employed as the collector solution. In the conventional MD experiments, a $20{ }^{\circ} \mathrm{C}$ temperature differential was applied, with the feed and collector streams maintained at 40 and $20^{\circ} \mathrm{C}$, respectively. In the comparison analysis, the feed and collector streams of isothermal MD were operated at the same temperature of $40{ }^{\circ} \mathrm{C}$ (i.e., same temperature as feed solution of $\mathrm{CMD}$ ). To investigate the effect of temperature on performance, IMD-AC was additionally operated with $T_{\mathrm{F}}=T_{\mathrm{C}}$ at 20,30,50, and 60 ${ }^{\circ} \mathrm{C}$. Volume of the feed and collector solutions are approximately 2.0 $\mathrm{L}$ each.

All experiments were conducted in a bench-scale MD unit (Figure S2 of Supporting Information). The feed and collector streams were circulated countercurrently at crossflow velocities of 22.2 and 20.0 $\mathrm{cm} / \mathrm{s}$, respectively, across the active membrane area of $19.0 \mathrm{~cm}^{2}$ in a custom-built membrane cell. $T_{\mathrm{F}}$ and $T_{\mathrm{C}}$ were regulated with heated and refrigerated circulators (PolyScience, Warrington, PA), respectively, through heat exchangers. Temperatures at the inlet and outlet of the membrane cell on the feed and collector sides were monitored using thermocouples (Omega Engineering, Norwalk, CT) and the solution within the cell was maintained within $\pm 1.5{ }^{\circ} \mathrm{C}$ of the target temperature throughout all experimental runs.

Ammonia vapor flux was determined from the rate of change of total ammoniacal nitrogen $\left(\mathrm{TAN}=\mathrm{NH}_{3}+\mathrm{NH}_{4}^{+}\right)$in the collector stream. Four $1 \mathrm{~mL}$ samples were taken every $15 \mathrm{~min}$, and TAN concentrations were measured following the Indophenol blue method. ${ }^{87}$ Ammonia salicylate and ammonia cyanurate reagent powder were added in excess to DI water-diluted samples and analyzed using a calibrated colorimeter (ThermoFisher Scientific). The change in moles of ammonia over time normalized by the membrane area yields $J_{\mathrm{A}}$. Additionally, $\mathrm{pH}$ of the collector stream was measured during sampling with a $\mathrm{pH}$ Meter (Orion Star, ThermoFisher Scientific). Water flux was calculated as the average rate of change in the feed and collector solution weights normalized by membrane area, accounting for the transferred ammonia and evaporative loss from bulk solution tanks. The change in weight of the feed and collector bulk solution tanks were automatically logged 
every $10 \mathrm{~s}$ using digital microbalances (AX5202, Ohaus, Parsippany, $\mathrm{NJ}$ ).

To demonstrate the potential of IMD-AC for high-recovery of ammonia, an isothermal MD experiment was conducted at $40{ }^{\circ} \mathrm{C}$ with the feed and collector solutions at the same initial ammoniacal nitrogen concentration. The feed solution was simulated urine (i.e., $500 \mathrm{mM}$ TAN), while the collector solution composition was 750 $\mathrm{mM}$ acetic acid and $500 \mathrm{mM}$ ammonium chloride (a higher acetic acid concentration than the earlier described experiments was employed to ensure collector stream $\mathrm{pH}$ was maintained sufficiently lower than the $\mathrm{p} K_{\mathrm{a}}$ of ammonia throughout the experiment duration). The experimental run was conducted for $6 \mathrm{~h}$, with ammonia concentrations in the collector stream measured every $1.5 \mathrm{~h}$.

\section{RESULTS AND DISCUSSION}

Higher Ammonia Selectivity is Achieved using Isothermal MD. Figure 2 shows ammonia and water vapor

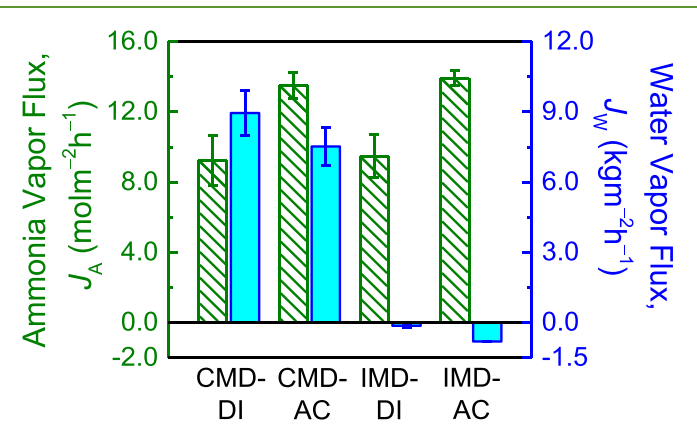

Figure 2. Ammonia and water vapor fluxes for four different $\mathrm{MD}$ operations: CMD-DI with $40{ }^{\circ} \mathrm{C}$ feed and $20{ }^{\circ} \mathrm{C}$ DI water collector, CMD-AC with $40{ }^{\circ} \mathrm{C}$ feed and $20^{\circ} \mathrm{C}$ acidic collector, IMD-DI with $40{ }^{\circ} \mathrm{C}$ feed and $40{ }^{\circ} \mathrm{C}$ DI water collector, and IMD-AC with $40{ }^{\circ} \mathrm{C}$ feed and $40{ }^{\circ} \mathrm{C}$ acidic collector. The feed stream for all scenarios is simulated solution of hydrolyzed urine $\left(250 \mathrm{mM} \mathrm{NH}_{4} \mathrm{OH}\right.$ and 250 $\mathrm{mM} \mathrm{NH}_{4} \mathrm{HCO}_{3}$ ), whereas acidic collector is $100 \mathrm{mM}$ acetic acid. The green patterned columns correspond to ammonia vapor fluxes (left vertical axis), and the blue solid columns denote water vapor fluxes (right vertical axis). Error bars indicate standard deviations of duplicate experiments with different membrane coupons.

fluxes (green patterned columns, left vertical axis and blue solid columns, right vertical axis, respectively) under CMD and IMD operation with DI water and acidic collector. For the same collector solution of DI water, $J_{\mathrm{A}}$ was practically consistent between conventional and isothermal MD $\left(9.25 \mathrm{molm}^{-2} \mathrm{~h}^{-1}\right.$ for CMD-DI and $9.47 \mathrm{molm}^{-2} \mathrm{~h}^{-1}$ for IMD-DI). At $40{ }^{\circ} \mathrm{C}, \mathrm{pH}$ of the simulated urine feed solution is 8.8 whereas $\mathrm{p} K_{\mathrm{a}}=8.8$ and, thus, volatile $\mathrm{NH}_{3(\mathrm{aq})}$ and $\mathrm{NH}_{4}^{+}$are of approximately equal concentrations $(\approx 250 \mathrm{mM})$. Isothermal operation of direct contact $\mathrm{MD}$ did not affect $\mathrm{NH}_{3(\mathrm{~g})}$ transport as the driving force for ammonia vapor permeation, $P_{\mathrm{F}, \mathrm{A}}-P_{\mathrm{C}, \mathrm{A}}$ is essentially equal for IMD and CMD (excluding temperature polarization effects, which will be discussed later) because the feed composition and temperature were held constant and ammonia concentration in the collector is negligible throughout the relatively short experiment duration. A comparison between CMD-AC and IMD-AC also presented minimal difference in $J_{\mathrm{A}}\left(13.5\right.$ and $13.9 \mathrm{molm}^{-2} \mathrm{~h}^{-1}$, respectively), further validating that ammonia vapor flux is not affected by warming the collector stream to $T_{\mathrm{F}}$ for isothermal MD operation. Effect of acidic collector on ammonia vapor fluxes is discussed in the next section.

In contrast to ammonia vapor permeation, water vapor fluxes were drastically different between IMD and CMD operation. Under CMD operation, water flux in the direction of feed to collector was significant, measuring 8.9 and $7.5 \mathrm{~kg}$ $\mathrm{m}^{-2} \mathrm{~h}^{-1}$ with DI water and acidic collector, respectively. The imposed $40-20{ }^{\circ} \mathrm{C}$ temperature differential in CMD set up a water vapor pressure gradient across the microporous membrane, which drove water vapor permeation from the feed to the collector side. $J_{\mathrm{W}}$ in IMD is markedly suppressed by over an order of magnitude to 0.13 and $0.80 \mathrm{~kg} \mathrm{~m}^{-2} \mathrm{~h}^{-1}$ for DI water and acidic collector, respectively. Elevation of $T_{\mathrm{C}}$ to match $T_{\mathrm{F}}$ in isothermal operation raised the water vapor pressure at the collector side to $\approx P_{\mathrm{F}, \mathrm{W}}$ (Figure $1 \mathrm{~B}$ ). Note that the effect of solution composition (i.e., DI water or $100 \mathrm{mM}$ acetic acid) on partial vapor pressure is negligible relative to the influence of temperature. The driving force for $J_{\mathrm{W}}$ is, therefore, effectively eliminated in IMD-DI and IMD-AC, i.e., $P_{\mathrm{F}, \mathrm{W}}-P_{\mathrm{C}, \mathrm{W}}=0$, and $\mathrm{H}_{2} \mathrm{O}$ transport was almost fully inhibited (eq 1).

Direction of the diminished $J_{\mathrm{W}}$ for IMD is opposite to CMD, i.e., water vapor permeated from collector to feed side (indicated as negative fluxes in Figure 2). The reversed water vapor flux is attributed to temperature polarization at the solution-membrane interfaces producing a slight local transmembrane temperature gradient toward the feed side. In $\mathrm{NH}_{3}$ transport, ammonia volatilizes from the feed stream at the membrane interface, permeates across the membrane, and solubilizes in the collector solution. These phase-changes necessary for $\mathrm{NH}_{3}$ transport in $\mathrm{MD}$ inevitably cool the feed and warm the collector solutions near the membrane surface, a phenomenon termed temperature polarization. ${ }^{88-90}$ Hence, even though the bulk solution temperatures are similar in IMD, there is a water vapor pressure gradient from collector to feed side, i.e., $P_{\mathrm{C}, \mathrm{W}}>P_{\mathrm{F}, \mathrm{W}}$, yielding negative $J_{\mathrm{W}}$ (illustrated in Figure S3 of Supporting Information). Temperature polarization likewise occurs in $\mathrm{CMD}$, but the bulk solution temperature difference overwhelms the local deviations. Thus, $P_{\mathrm{F}}>P_{\mathrm{C}}$ and water and ammonia vapor fluxes are always positive, i.e., from feed to collector side.

For the separation and recovery of ammoniacal nitrogen from hydrolyzed urine, high ammonia vapor permeation and minimal water vapor flux are desired to minimize energy required for vaporization enthalpy and limit watering down of the product (i.e., collector stream effluent). That is, selective transport of $\mathrm{NH}_{3}$ over $\mathrm{H}_{2} \mathrm{O}$ is advantageous. Figure 3 presents

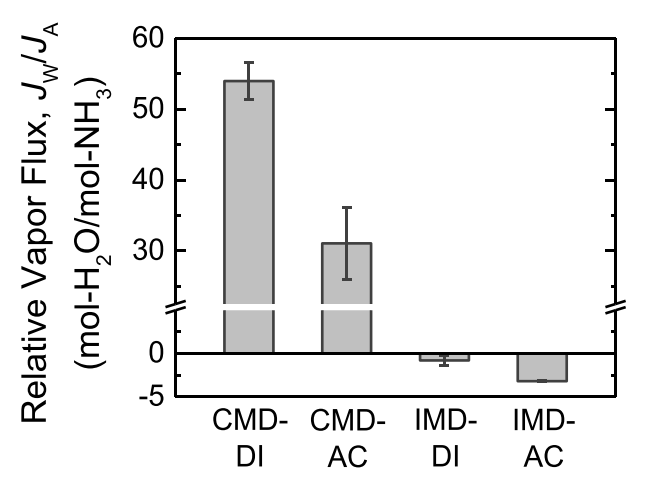

Figure 3. Relative molar flux of water to ammonia for the four operations, CMD-DI, CMD-AC, IMD-DI, and IMD-AC. IMD-DI and IMD-AC exhibit negative relative fluxes because water vapor permeation was in opposite direction, from collector to feed side. Error bars indicate standard deviations of duplicate experiments with different membrane coupon. 
the relative molar flux of water to ammonia for the four operating conditions, with a lower $J_{\mathrm{W}} / J_{\mathrm{A}}$ signifying better selectivity for ammonia transport. The magnitude of $J_{\mathrm{W}} / J_{\mathrm{A}}$ for conventional operation is significantly higher than the isothermal processes (negative values for IMD reflect the reversed direction of water vapor permeation). For every mole of ammonia volatilized from the feed stream, 54 and 31 moles of water are simultaneously evaporated in CMD-DI and CMD$\mathrm{AC}$, respectively, underscoring that thermal energy input for vaporization enthalpy is predominantly consumed for $\mathrm{H}_{2} \mathrm{O}$ and not the intended $\mathrm{NH}_{3}$ (detailed energy analysis is presented in a later section). The poor selectivity of CMD is attributed to the concentration of water being about $100 \times$ higher than ammonia in the simulated urine stream $\left(\approx 55.5 \mathrm{~mol}^{-\mathrm{H}_{2} \mathrm{O} / \mathrm{L}}\right.$ compared to $\left.0.5 \mathrm{~mol}-\mathrm{NH}_{3} / \mathrm{L}\right)$, overwhelming the effect of greater volatility of ammonia than water. The transport of water in isothermal MD was suppressed by up to $68 \times$ compared to conventional operation $(-0.803$ and -3.02 mol$\mathrm{H}_{2} \mathrm{O} / \mathrm{mol}^{-\mathrm{NH}_{3}}$ for IMD-DI and IMD-AC, respectively), highlighting the enhanced selectivity of IMD for ammonia separation and recovery. The relative vapor flux in $\mathrm{kg}-\mathrm{H}_{2} \mathrm{O}$ / mol- $\mathrm{NH}_{3}$ is presented in Figure $\mathrm{S} 4$ of the Supporting Information.

Acidic Collector Enhances Ammonia Vapor Flux. Under acidic collector operation, CMD-AC and IMD-AC, ammonia vapor fluxes were, on average, $46.5 \%$ higher than with DI water, CMD-DI and IMD-DI (green patterned columns, left vertical axis of Figure 2). As ammonia permeates from feed to collector, $\mathrm{pH}$ of the collector rose above 10 when DI water was used, but remained below 4 with acetic acid as the collector (Figure S5). At solution temperatures of 20 and $40{ }^{\circ} \mathrm{C}, \mathrm{pK} \mathrm{A}_{\mathrm{A}}$ of $\mathrm{NH}_{3(\mathrm{aq})}$ was 9.4 and 8.8, respectively. Consequentially, ammoniacal nitrogen is predominantly in the form of ammonia, $\mathrm{NH}_{3(\mathrm{aq})}$, in DI water collector, whereas ammonia protonates to nonvolatile ammonium, $\mathrm{NH}_{4}^{+}$, in the acidic collectors.

Because ammonia present in the DI water collector exhibits vapor pressure, i.e., $P_{\mathrm{C}, \mathrm{A}}>0$, the driving force for $\mathrm{NH}_{3}$ permeation, $P_{\mathrm{F}, \mathrm{A}}-P_{\mathrm{C}, \mathrm{A}}$, is lowered. However, vapor pressure generated by $\mathrm{NH}_{3(\mathrm{aq})}$ in the $\mathrm{DI}$ water collector is marginal and, hence, does not fully account for the difference in $J_{\mathrm{A}}$ between DI water and acidic collector. At the end of the hour-long experiments, ammonia concentration in the collector only reached 8.43 and $8.66 \mathrm{mM}$ for CMD-DI and IMD-DI, respectively, equivalent to a reduction in ammonia vapor pressure gradient of 1.5 and $3.8 \%$ (drop for isothermal operation is higher because the collector stream is at $40{ }^{\circ} \mathrm{C}$, as opposed to $20^{\circ} \mathrm{C}$ for conventional operation). In contrast, the decrease in ammonia vapor fluxes when the collector is DI water instead of acetic acid was $31.6 \%$ and $32.0 \%$ for CMD and IMD, respectively. Therefore, the slight decline in $P_{\mathrm{A}}$ gradient when TAN is present as $\mathrm{NH}_{3(\mathrm{aq})}$ does not adequately explain the considerably smaller $J_{\mathrm{A}}$ with DI water collector.

An increase in ammonia vapor flux when acidic solutions were utilized as collector had been reported, ${ }^{62,91}$ but the mechanism was not discussed. We postulate that the $J_{\mathrm{A}}$ enhancement is due to the acidic solution improving the kinetics of ammonia vapor dissolution into the aqueous phase. At the collector side vapor-liquid interface, some ammonia molecules incident on the liquid surface are reflected back into the vapor phase, i.e., condensation coefficient $<1,{ }^{92}$ resulting in the $\mathrm{NH}_{3(\mathrm{~g})}$ solubilization rate being slower than the initial rate of ammonia permeation. The molecular reflection builds up the partial vapor pressure of ammonia at the interface and results in $P_{\mathrm{C}, \mathrm{A}}>K_{\mathrm{H}} \mathcal{c}_{\mathrm{C}, \mathrm{A}}$, where $K_{\mathrm{H}}$ is Henry's constant for $\mathrm{NH}_{3}{ }^{92}$ That is, the vapor-liquid interface at the collector side is not at thermodynamic equilibrium. When a nonacidic solution, such as DI water, is employed for the collector stream, the ammonia solubilization kinetics is slow and the eventual steady-state effective driving force is considerably lessened due to the elevated interfacial $P_{\mathrm{C}, \mathrm{A}} . \mathrm{NH}_{3(\mathrm{~g})}$ dissolves significantly faster into an acidic solution, ${ }^{93}$ i.e., condensation coefficient is increased, giving rise to a larger $P_{\mathrm{F}, \mathrm{A}}-P_{\mathrm{C}, \mathrm{A}}$ and yielding markedly enhanced ammonia vapor flux. Therefore, the use of AC beneficially improves ammonia separation and recovery by mitigating the kinetic limitation of ammonia dissolution.

Ammonia Vapor Flux Increases with Greater Feed Temperature. To investigate the influence of temperature on IMD-AC performance, ammonia and water vapor fluxes were characterized as a function of feed and collector solution temperature and presented in Figure 4 (green square symbols,

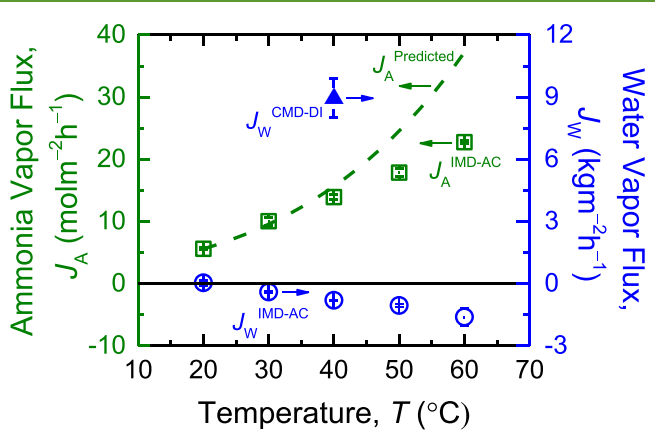

Figure 4. Experimental IMD-AC ammonia and water vapor fluxes (green square symbols, left vertical axis; blue circle symbols, right vertical axis, respectively) as a function of operating temperature. Predicted ammonia vapor flux, calculated using eq 1 with membrane vapor permeability coefficient at $20{ }^{\circ} \mathrm{C}\left(L_{\mathrm{A}}=0.021 \mathrm{molm}^{-2} \mathrm{~h}^{-1} \mathrm{pa}^{-1}\right)$, is represented by the green dashed line. For comparison, the water vapor flux in IMD-DI with feed and collector solutions at 40 and 20 ${ }^{\circ} \mathrm{C}$, respectively, is denoted by the blue triangle symbol. Error bars indicate standard deviations of duplicate experiments with different membrane coupon.

left vertical axis and blue circle symbols, right vertical axis, respectively). Ammonia vapor flux monotonically increased from 5.60 to $22.8 \mathrm{molm}^{-2} \mathrm{~h}^{-1}$ (approximately 4-fold) as operating temperatures were raised from 20 to $60{ }^{\circ} \mathrm{C}$. Critically, the magnitude of water vapor flux was suppressed to below $\approx 2 \mathrm{~kg} \mathrm{~m}^{-2} \mathrm{~h}^{-1}$ across the assessed temperature range, substantially smaller compared to $J_{\mathrm{W}}$ in CMD (blue triangle symbol in Figure 4 for feed and collector solutions at 40 and 20 ${ }^{\circ} \mathrm{C}$, respectively). As discussed earlier, the direction of water vapor permeation in IMD operation is reversed, i.e., from collector to feed side. This reverse water vapor flux increased with increasing temperature. This is because ammonia permeation is enhanced at higher temperatures and, thus, more heat of vaporization was transferred from the feed to collector side, causing more severe temperature polarization at the solution-membrane interfaces (previously elaborated and illustrated by Figure S3 of Supporting Information). Hence, the transmembrane temperature gradient is more pronounced at higher temperatures, resulting in greater reverse water vapor permeation. 
Low relative vapor flux of water to ammonia for IMD-AC was, again, consistently attained across the temperatures investigated (Figure S6 of Supporting Information). Magnitude of relative flux increased slightly with higher temperatures but was maintained below $-0.1 \mathrm{~kg}-\mathrm{H}_{2} \mathrm{O} / \mathrm{mol}^{-\mathrm{NH}_{3}}$ (marginally positive $J_{\mathrm{W}} / J_{\mathrm{A}}$ at $20{ }^{\circ} \mathrm{C}$ is attributed to inherent experimental uncertainties in measuring very small water fluxes). Crucially, ammonia permeation was obtained with adequate $\mathrm{NH}_{3}-\mathrm{H}_{2} \mathrm{O}$ flux selectivity even at the lowest investigated temperature of $20{ }^{\circ} \mathrm{C}$, which is effectively ambient condition. Hence, the separation and recovery of ammonia from hydrolyzed urine can potentially be achieved, albeit at slower rates, without heating the feed and collector streams to elevate the temperatures.

With negligible $\mathrm{NH}_{3(\mathrm{aq})}$ concentration in the collector stream, the higher vapor pressure of ammonia at the feed side due to the greater solution temperature results in an augmented driving force for $\mathrm{NH}_{3(\mathrm{~g})}$ permeation. However, $J_{\mathrm{A}}$ enhancements with increasing temperature is poorly predicted by the governing flux equation, eq 1 , and the ClausiusClapeyron relation. Using the ammonia vapor pressure gradient at each temperature and membrane vapor permeability coefficient at $20{ }^{\circ} \mathrm{C}\left(L_{\mathrm{A}}=0.022 \mathrm{molm}^{-2} \mathrm{~h}^{-1} \mathrm{~Pa}^{-1}\right)$, ammonia vapor fluxes were computed and shown in Figure 4 as the green dashed line. Theoretical calculations overestimate the experimental ammonia vapor fluxes, with greater deviations observed at higher temperatures. In theory, an exponential increase in $J_{\mathrm{A}}$ was forecasted with rising temperature, due to the exponential dependence of vapor pressure on temperature, but an effectively linear increase in experimental ammonia vapor flux was seen.

One potential explanation for the experimental deviation from expected trend is kinetic limitation for ammonia solubilization into the collector solution (as discussed in the preceding section) being more pronounced at higher temperatures. Alternatively/additionally, $\mathrm{NH}_{3}$ volatilization from the feed solution can be a rate-limiting factor. In the earlier section, we discussed that the liquid and vapor phases at the solutionmembrane interfaces are not in equilibrium because ammonia vapor transport across the membrane pores is faster than $\mathrm{NH}_{3}$ volatilizing from the feed stream and/or dissolving into the collector stream. ${ }^{92,94,95}$ Therefore, the effective vapor pressures of ammonia at the feed and collector interfaces are lower and higher, respectively, than the equilibrium $P_{\mathrm{A}}$ as governed by Henry's law, i.e., $P_{\mathrm{F}, \mathrm{A}}<K_{\mathrm{H}} \mathcal{c}_{\mathrm{F}, \mathrm{A}}$ and $P_{\mathrm{C}, \mathrm{A}}>K_{\mathrm{H}} \mathcal{c}_{\mathrm{C}, \mathrm{A}}$. Given larger ammonia vapor fluxes are obtained at higher IMD operating temperatures, the effect of volatilization and solubilization kinetic limitations is, thus, expected to be more amplified. Consequently, the relative reduction in effective driving force, $P_{\mathrm{F}, \mathrm{A}}-P_{\mathrm{C}, \mathrm{A}}$ is greater and actual $J_{\mathrm{A}}$ deviates further from prediction (Figure 4).

Another possible cause contributing to the observed disagreement is that water vapor transport in the reverse direction during IMD hinders ammonia permeation. As described by Maxwell-Stefan diffusion, mutual interaction between the $\mathrm{NH}_{3}$ and $\mathrm{H}_{2} \mathrm{O}$ molecules results in frictional drag on the transport of ammonia by water vapor permeating in the opposite direction. ${ }^{96-98}$ This resistance to $\mathrm{NH}_{3(\mathrm{~g})}$ transport scales with the magnitude of reverse $\mathrm{H}_{2} \mathrm{O}_{(\mathrm{g})}$ flux. Reverse water vapor transport is greater at higher operating temperatures (blue circle symbols of Figure 4) and, hence, the discrepancy between theoretical and experimental fluxes is wider.
A third phenomenon that causes experimental fluxes to diverge from calculated $J_{\mathrm{A}}$ is temperature polarization. ${ }^{88,89}$ As discussed earlier, although the bulk solution streams are at the same temperature in IMD, a transmembrane temperature gradient is set up from the collector to feed sides (Figure S3 of Supporting Information), due to the transfer of $\mathrm{NH}_{3}$ volatilization/condensation enthalpy. Interfacial temperature at the feed and collector sides are, hence, lower and higher, respectively, than the bulk solution temperatures. Thus, the effective driving force for ammonia permeation, $P_{\mathrm{F}, \mathrm{A}}-P_{\mathrm{C}, \mathrm{A}}$ is lesser than the calculated value using bulk solution temperatures. The observed reverse water vapor flux is greater at higher temperatures, indicating that the transmembrane temperature gradient is steeper, i.e., temperature polarization is more acute. Therefore, the deviation between experimental and predicted $J_{\mathrm{A}}$ is anticipated to be larger with increasing temperatures. This mechanism is supported by previous studies that reported decreased apparent membrane vapor transport coefficient with higher temperatures, (i.e., temperature polarization effects incorporated into $L) .^{54,56}$

High Ammonia Recovery can be Achieved using IMD-AC. To investigate the potential ammonia recovery yield achievable with IMD-AC from source-separated urine, a batch experiment was conducted with closed-loop recirculation of the solutions across the bench-scale membrane cell, which equivalently simulates cocurrent flow configuration in a process-scale membrane module. Feed stream TAN (= $\mathrm{NH}_{3}+\mathrm{NH}_{4}^{+}$) concentration is $500 \mathrm{mM}$ to represent hydrolyzed urine, whereas collector stream is $750 \mathrm{mM}$ acetic acid (higher concentration was employed to avoid $\mathrm{pH}$ increases limiting ammonia transport) and $500 \mathrm{mM}$ TAN, i.e., total ammoniacal nitrogen is equal on both sides. TAN concentration of the feed and collector streams in IMD-AC at $40{ }^{\circ} \mathrm{C}$ as a function of time is presented in Figure 5 (green circle and square symbols, respectively).

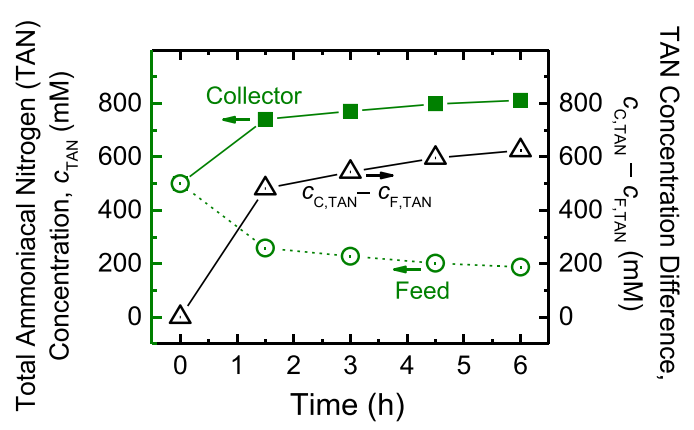

Figure 5. Total ammoniacal nitrogen, TAN, concentration in the feed and collector streams in IMD-AC operation at $40{ }^{\circ} \mathrm{C}$ as a function of time (left vertical axis, green circle and square symbols, respectively). Feed stream has $500 \mathrm{mM}$ TAN to simulate hydrolyzed urine and collector solution is $500 \mathrm{mM}$ TAN and $750 \mathrm{mM}$ acetic acid (i.e., same initial TAN concentrations for both feed and collector solutions). The black triangle symbols (right vertical axis) represent the difference between the concentration of TAN in the collector and feed streams, i.e., $c_{\mathrm{C}, \mathrm{TAN}}-\mathcal{c}_{\mathrm{F}, \mathrm{TAN}}$.

After $1.5 \mathrm{~h}$, collector TAN concentration increased to 741 $\mathrm{mM}$ while $c_{\mathrm{F}, \mathrm{TAN}}$ dropped to $259 \mathrm{mM}$, representing $\mathrm{NH}_{3}$ separation and recovery of $48.2 \%$. Comparatively, TAN recovery in IMD at $40{ }^{\circ} \mathrm{C}$ with a DI water collector stream was only $2.7 \%$ for the same time period (projected using $J_{\mathrm{A}}$ of the first $60 \mathrm{~min}$ ). At the end of $6 \mathrm{~h}, \approx 60 \%$ of TAN in the 
simulated urine was removed and captured in the collector stream, demonstrating the potential for high ammonia recovery using IMD-AC. Water flux was practically negligible and solution volumes are effectively unchanged $(<1 \%$ difference after $6 \mathrm{~h}$ ). As ammonia permeates from the feed to collector side, TAN concentration and, correspondingly, volatile $\mathrm{NH}_{3 \text { (aq) }}$ concentration of the feed solution decreases. Consequently, ammonia vapor pressure, $P_{\mathrm{F}, \mathrm{A}}$, falls and the driving force for ammonia permeation, $P_{\mathrm{F}, \mathrm{A}}-P_{\mathrm{C}, \mathrm{A}}$, declines over time, which is evident by the diminishing rate of change of TAN concentration. Final $\mathrm{pH}$ of the collector solution is 3.5. Given the $\mathrm{p} K_{\mathrm{a}}$ of ammonia at $40{ }^{\circ} \mathrm{C}$ is 8.8 , effectively $100 \%$ of TAN in the bulk collector solution was present as nonvolatile ammonium, $\mathrm{NH}_{4}{ }^{+}$. Hence, $\mathrm{NH}_{3(\mathrm{aq})}$ concentration was negligible, i.e., $c_{\mathrm{C}, \mathrm{A}} \approx 0$, and ammonia vapor pressure in the collector, $P_{\mathrm{C}, \mathrm{A}}$, is practically zero.

Crucially, the difference in TAN between the collector and feed solutions, $c_{\mathrm{C}, \mathrm{TAN}}-c_{\mathrm{F}, \mathrm{TAN}}$, increased from 0 to $\approx 600 \mathrm{mM}$ (black triangle symbols of Figure 5), indicating transport of ammoniacal nitrogen up a concentration gradient. The "uphill" transport of TAN shows IMD-AC can concentrate ammoniacal nitrogen significantly above the initial $c_{\mathrm{F}, \mathrm{TAN}}$. In actual modulescale operation, the feed and collector streams will be circulated in counter-current flow and higher recovery yields of ammonia can be achieved with lower acid concentrations in the collector solution.

Substantial Energy Saving is Obtained with IMD. In membrane distillation, thermal energy is required for the vaporization enthalpy of volatile components that permeate across the membrane. ${ }^{55,90,99}$ Convective heat flux of component $i$ is the product of the vaporization enthalpy, $\Delta H_{i}$, and the flux, $J_{i \cdot}{ }^{55}$ Figure 6 shows the vaporization energy for ammonia and water (green patterned and blue solid columns, respectively) in the four operating modes. To exclude the influence of different kinetics (i.e., different $\mathrm{NH}_{3(\mathrm{~g})}$ fluxes), $\Delta H_{i} J_{i}$ is divided by $J_{\mathrm{A}}$ to yield energy per mole of ammonia recovered, $E_{\mathrm{V}, i}$. Sum of the ammonia and water components

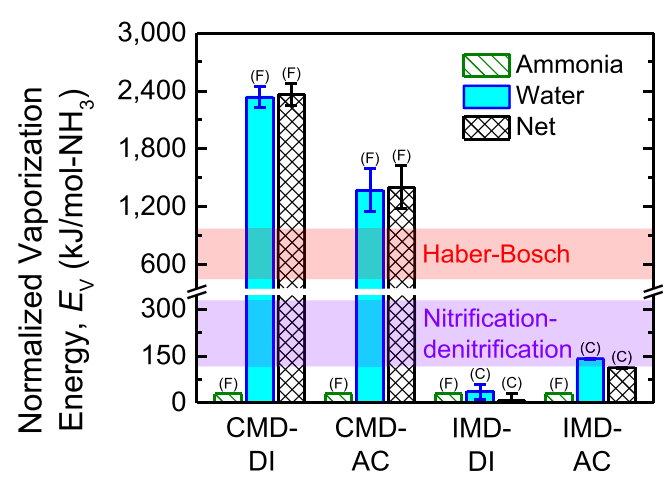

Figure 6. Vaporization energy for ammonia and water (green patterned and blue solid columns, respectively) per mole of ammonia separated and recovered in CMD-DI, CMD-AC, IMD-DI, and IMDAC. Labels (F) and (C) above the columns denote heat supply to feed and collector streams, respectively. Patterned black columns represent the net vaporization energies of ammonia and water, i.e., I $\sum E_{\mathrm{V},(\mathrm{F})}-\sum E_{\mathrm{V},(\mathrm{C})} \mathrm{l}$. Error bars for vaporization of water are standard deviations of duplicate water vapor flux measurements. For comparison, the red- and violet-shaded regions indicate energy required by the Haber-Bosch process, $448-973 \mathrm{~kJ} / \mathrm{mol}-\mathrm{NH}_{3}(8.89-$ $19.3 \mathrm{kWh} / \mathrm{kg}-\mathrm{N})$, and nitrification-denitrification, $116-328 \mathrm{~kJ} / \mathrm{mol}-$ $\mathrm{NH}_{3}(2.3-6.5 \mathrm{kWh} / \mathrm{kg}-\mathrm{N})$, respectively. gives the net normalized vaporization energy (black patterned columns), $\left|\sum E_{\mathrm{V}, i}\right|=\left|J_{\mathrm{A}}^{-1} \sum \Delta H_{j_{i}}\right|=\left|\Delta H_{\mathrm{A}}+\Delta H_{\mathrm{W}} J_{\mathrm{W}} / J_{\mathrm{A}}\right|$ (note that $J_{i}$ can be negative and the impact on energy required is discussed later). Determination of enthalpy of ammonia vaporization from an aqueous solution, as opposed to a pure liquid, is presented in the Supporting Information, and $\Delta H_{i}$ at the relevant stream temperatures were used in the analysis. $^{100,101}$

While normalized energy demands for the vaporization of ammonia, $E_{\mathrm{V}, \mathrm{A}}$ in the four different operating conditions are the same at $28.4 \mathrm{~kJ} / \mathrm{mol}^{-\mathrm{NH}_{3}}$ (due to normalization by $J_{\mathrm{A}}$ ), the heat to vaporize water, $E_{\mathrm{V}, \mathrm{W}}$, varies markedly because it is dependent on the relative vapor flux of water to ammonia (Figure 3). In the conventional MD operations of CMD-DI and $\mathrm{CMD}-\mathrm{AC}$, considerable thermal energies of 2340 and $1370 \mathrm{~kJ} / \mathrm{mol}-\mathrm{NH}_{3}$ (46.4 and $27.2 \mathrm{kWh} / \mathrm{kg}-\mathrm{N}$ ), respectively, are required to evaporate water from the feed solution, 82.4 and $48.2 \times$ the energy to volatilize ammonia. The high heat input is because of the large magnitude of inevitable water vapor flux in conventional MD. In contrast, due to suppression of water transport in isothermal $\mathrm{MD}, E_{\mathrm{V}, \mathrm{W}}$ is substantially lessened to 35.4 and $141 \mathrm{~kJ} / \mathrm{mol}^{-\mathrm{NH}_{3}}(0.702$ and $2.80 \mathrm{kWh} / \mathrm{kg}-\mathrm{N})$ for IMD-DI and IMD-AC, respectively. Since the direction of $J_{\mathrm{W}}$ is from the collector to feed side in IMD, i.e., reversed, heat is required for water vaporization at the collector stream (instead of feed side) and is indicated by the label (C). Thermal energy for enthalpy of vaporization is transferred to the other side as enthalpy of condensation when the vapor permeates across the membrane and solubilizes into the aqueous stream. Therefore, the net normalized energy input is the difference between $E_{\mathrm{V}}$ on the feed and collector sides (black patterned columns). Compared to CMD-DI, IMD-AC requires $95.2 \%$ less heat input for vaporization to separate and recover the same amount of ammonia by inhibiting undesired water flux (Figure 2). Higher energy savings of $99.7 \%$ is achievable with IMD-DI, but $\mathrm{NH}_{3}$ recovery yield would be constrained (as discussed in preceding section).

In addition to convective heat flux discussed above, conduction of heat through the membrane is another thermal energy requirement. ${ }^{99,102,103}$ Conductive heat flux is proportional to the transmembrane temperature differential. Conventional MD necessitates a temperature difference between the feed and collector solutions, whereas the bulk stream temperatures are equal in isothermal MD. Therefore, the temperature gradient across the membrane in IMD is significantly smaller than CMD (Figures 1 and S3) and consequently, conductive heat loss is expected to be minimized in isothermal operation. Moreover, transmembrane heat conduction drives the feed and collector solutions toward temperature equilibrium, which is the working principle of isothermal $\mathrm{MD}$ but is against the operation of conventional MD.

Overall, isothermal MD favorably reduces the energy consumption for ammonia removal and reuse by substantially lowering both convective and conductive heat input. Compared to energy demand for the current linear economy management of nitrogen, i.e., production by the Haber-Bosch process and removal by conventional nitrification-denitrification, the vaporization energy required for $\mathrm{NH}_{3}$ recovery in IMD is significantly lower. Energy demand for $\mathrm{N}$ fixation by the Haber-Bosch process, the principal ammonia production method, is $8.9-19.3 \mathrm{kWh} / \mathrm{kg}-\mathrm{N}$ (448-973 $\mathrm{kJ} / \mathrm{mol}^{-\mathrm{NH}_{3}}$, 
indicated by the red-shaded region in Figure 6). Conventional removal of nitrogen by nitrification and denitrification at wastewater treatment plants demands $2.3-6.5 \mathrm{kWh} / \mathrm{kg}-\mathrm{N}$ (116-328 $\mathrm{kJ} / \mathrm{mol}-\mathrm{NH}_{3}$, indicated by the violet-shaded region). Vaporization energy needed for isothermal $\mathrm{MD}$ is around an order of magnitude lower than the Haber-Bosch energy consumption benchmark and is in the same range as nitrification-denitrification. Actual energy requirement for a practical IMD-AC system to remove and recover ammonia from diverted urine will have to factor in auxiliary components (e.g., pumping cost, conductive losses, and heat exchanger efficiency) and module-scale effects, but the first-order energy analysis conducted here highlights potential of the technology to be a competitive alternative to current $\mathrm{NH}_{3}$ production and removal methods.

\section{IMPLICATIONS}

The removal of ammonia from wastewaters is imperative for environmental, ecological, and public health protection. At the same time, nitrogen is a principal component of fertilizer. The high ammonia content in urine offers attractive opportunities to simultaneously recover the resource and remove the contaminant from the waste stream. To align with the principles of green engineering and realize viable implementation, the ammonia separation and recovery approach needs to be energy-efficient. ${ }^{36}$ This study demonstrates isothermal membrane distillation with acidic collector can achieve (i) selective removal and capture of ammonia from hydrolyzed urine with (ii) low thermal energy requirements and (iii) high recovery yield.

Importantly, because only mild temperatures are needed to drive the process, isothermal MD can utilize low-grade heat from locally available waste flows (e.g., warm bathwater runoff or hot stream of cooling water systems) or onsite lowconcentration solar thermal collectors, ${ }^{104-106}$ further enhancing the sustainability of the technology. The study also showed that ammonia separation and recovery is possible even at ambient temperatures, i.e., without further warming up the feed and collector streams, at the expense of lower fluxes. Acid for the collector solution can be from unwanted effluent streams, such as spent pickling brine, which is effectively vinegar (i.e., acetic acid), from the food industry. ${ }^{107,108}$ This study examined the use of acetic acid, but other suitable acids from waste/low-cost sources can be employed. Additionally, IMD-AC can drive the uphill transport of ammoniacal nitrogen to achieve highly concentrated $\mathrm{NH}_{3}$ solutions as product, favorably minimizing the liquid volume for handling and transport. Crucially, vaporization energy requirement for isothermal MD is substantially below the energy demand for fossil fuel-driven Haber-Bosch process, the dominant ammonia production method, and comparable to energy consumption for $\mathrm{N}$ removal at conventional WWTPs. Further technoeconomic assessments are needed to quantify the capital and operating expenditure of IMD-AC, but the technology shows initial promise to be a cost-competitive and environmentally sensible technique for removing and recovering ammonia from source-separated urine.

With the projected urban influx of 2.5 billion people by $2050,{ }^{109}$ the population density of cities is expected to increase dramatically. At the same time, providing improved sanitation to the 2.3 billion people globally who are currently unserved will necessitate the installation of new toilets, wastewater facilities, and sanitation infrastructure. ${ }^{110}$ These population and sanitation trends present ideal opportunities for the introduction of decentralized urine diversion facilities for nutrient recovery, without costly retrofits or overhauls of the existing system, shifting wastewater management to a more sustainable and efficient paradigm.

Other potential applications of the technology include the selective separation/recovery of compounds that speciate between volatile and nonvolatile forms at different $\mathrm{pH}$. An environmentally relevant example is $\mathrm{H}_{2} \mathrm{~S}$ in domestic and industrial wastewaters. ${ }^{111}$ Because of the $\mathrm{pH}$-dependent volatility, $\mathrm{H}_{2} \mathrm{~S}_{(\mathrm{g})}$ permeates across the $\mathrm{MD}$ membrane and speciates to nonvolatile $\mathrm{HS}^{-}{ }_{\text {(aq) }}$ in a basic collector (equivalent to $\mathrm{NH}_{3(\mathrm{~g})}$ transport and speciation to $\mathrm{NH}_{4}^{+}{ }_{(\mathrm{aq})}$ ), thus, enabling selective removal, capture, and concentration.

\section{ASSOCIATED CONTENT}

\section{Supporting Information}

The Supporting Information is available free of charge at https://pubs.acs.org/doi/10.1021/acssuschemeng.0c00643.

Determination of ammonia and water vapor pressures; speciation of total ammoniacal nitrogen (Figure S1); bench-scale membrane distillation setup utilized in experiments (Figure S2); temperature and vapor pressure profiles in membrane distillation (Figure S3); relative vapor flux of water to ammonia in $\mathrm{kg}-\mathrm{H}_{2} \mathrm{O} / \mathrm{mol}$ $\mathrm{NH}_{3}$ for each operation (Figure S4); collector solution $\mathrm{pH}$ as a function of time under each operation (Figure $\mathrm{S5}$ ); relative molar flux of water to ammonia in IMD-AC as a function of temperature (Figure S6); determination of the vaporization enthalpy of ammonia from aqueous solutions (PDF)

\section{AUTHOR INFORMATION}

\section{Corresponding Author}

Ngai Yin Yip - Department of Earth and Environmental

Engineering and Columbia Water Center, Columbia University, New York, New York 10027-6623, United States; (1) orcid.org/0000-0002-1986-4189; Phone: +1 212

8542984; Email: n.y.yip@columbia.edu

\section{Authors}

Stephanie N. McCartney - Department of Earth and Environmental Engineering, Columbia University, New York, New York 10027-6623, United States

Natalie A. Williams - Department of Earth and Environmental Engineering, Columbia University, New York, New York 100276623, United States

Chanhee Boo - Department of Earth and Environmental Engineering, Columbia University, New York, New York 100276623, United States; (1) orcid.org/0000-0003-4595-9963

Xi Chen - Department of Earth and Environmental Engineering, Columbia University, New York, New York 10027-6623, United States

Complete contact information is available at:

https://pubs.acs.org/10.1021/acssuschemeng.0c00643

\section{Notes}

The authors declare no competing financial interest.

\section{ACKNOWLEDGMENTS}

This material is based upon work supported by the National Science Foundation under Grant No. 1903705. 


\section{REFERENCES}

(1) NAE Grand Challenges for Engineering. https://www.nae.edu/ File.aspx?id=187214 (Accessed on 02/20/2019).

(2) Steffen, W.; Richardson, K.; Rockstrom, J.; Cornell, S. E.; Fetzer, I.; Bennett, E. M.; Biggs, R.; Carpenter, S. R.; de Vries, W.; de Wit, C. A.; Folke, C.; Gerten, D.; Heinke, J.; Mace, G. M.; Persson, L. M.; Ramanathan, V.; Reyers, B.; Sorlin, S. Planetary boundaries: Guiding human development on a changing planet. Science 2015, 347 (6223), 1259855.

(3) Michalak, A. M.; Anderson, E. J.; Beletsky, D.; Boland, S.; Bosch, N. S.; Bridgeman, T. B.; Chaffin, J. D.; Cho, K.; Confesor, R.; Daloglu, I.; DePinto, J. V.; Evans, M. A.; Fahnenstiel, G. L.; He, L.; Ho, J. C.; Jenkins, L.; Johengen, T. H.; Kuo, K. C.; LaPorte, E.; Liu, X.; McWilliams, M. R.; Moore, M. R.; Posselt, D. J.; Richards, R. P.; Scavia, D.; Steiner, A. L.; Verhamme, E.; Wright, D. M.; Zagorski, M. A. Record-setting algal bloom in Lake Erie caused by agricultural and meteorological trends consistent with expected future conditions. Proc. Natl. Acad. Sci. U. S. A. 2013, 110 (16), 6448-6452.

(4) Conley, D. J.; Paerl, H. W.; Howarth, R. W.; Boesch, D. F.; Seitzinger, S. P.; Havens, K. E.; Lancelot, C.; Likens, G. E. Ecology Controlling eutrophication: Nitrogen and phosphorus. Science 2009, 323, 1014-1015.

(5) Diaz, R. J.; Rosenberg, R. Spreading dead zones and consequences for marine ecosystems. Science 2008, 321, 926-929.

(6) Brooks, B. W.; Lazorchak, J. M.; Howard, M. D. A.; Johnson, M. V. V.; Morton, S. L.; Perkins, D. A. K.; Reavie, E. D.; Scott, G. I.; Smith, S. A.; Steevens, J. A. Are Harmful Algal Blooms Becoming the Greatest Inland Water Quality Threat to Public Health and Aquatic Ecosystems? Environ. Toxicol. Chem. 2016, 35 (1), 6-13.

(7) Hitzfeld, B. C.; Hoger, S. J.; Dietrich, D. R. Cyanobacterial toxins: Removal during drinking water treatment, and human risk assessment. Environ. Health Persp. 2000, 108, 113-122.

(8) Environmental Protection Agency. Clean Watersheds Needs Survey In 2012.

(9) Rahman, S. M.; Eckelman, M. J.; Onnis-Hayden, A.; Gu, A. Z. Life-Cycle Assessment of Advanced Nutrient Removal Technologies for Wastewater Treatment. Environ. Sci. Technol. 2016, 50, 3020.

(10) Maurer, M.; Schwegler, P.; Larsen, T. A. Nutrients in urine: energetic aspects of removal and recovery. Water Sci. Technol. 2003, 48 (1), 37-46.

(11) Mulder, A. The quest for sustainable nitrogen removal technologies. Water Sci. Technol. 2003, 48 (1), 67-75.

(12) Wett, B. Development and implementation of a robust deammonification process. Water Sci. Technol. 2007, 56 (7), 81-88.

(13) Schaubroeck, T.; De Clippeleir, H.; Weissenbacher, N.; Dewulf, J.; Boeckx, P.; Vlaeminck, S. E.; Wett, B. Environmental sustainability of an energy self-sufficient sewage treatment plant: Improvements through DEMON and co-digestion. Water Res. 2015, 74, 166-179.

(14) Erisman, J. W.; Sutton, M. A.; Galloway, J.; Klimont, Z.; Winiwarter, W. How a century of ammonia synthesis changed the world. Nat. Geosci. 2008, 1 (10), 636-741.

(15) Fowler, D.; Coyle, M.; Skiba, U.; Sutton, M. A.; Cape, J. N.; Reis, S.; Sheppard, L. J.; Jenkins, A.; Grizzetti, B.; Galloway, J. N.; Vitousek, P.; Leach, A.; Bouwman, A. F.; Butterbach-Bahl, K.; Dentener, F.; Stevenson, D.; Amann, M.; Voss, M. The global nitrogen cycle in the Twentyfirst century. Philos. Trans. R. Soc., B 2013, 368 (1621), 20130164.

(16) Chen, J. G.; Crooks, R. M.; Seefeldt, L. C.; Bren, K. L.; Bullock, R. M.; Darensbourg, M. Y.; Holland, P. L.; Hoffman, B.; Janik, M. J.; Jones, A. K.; Kanatzidis, M. G.; King, P.; Lancaster, K. M.; Lymar, S. V.; Pfromm, P.; Schneider, W. F.; Schrock, R. R. Beyond fossil fueldriven nitrogen transformations. Science 2018, 360, 6391.

(17) Li, W. W.; Yu, H. Q.; Rittmann, B. E. Chemistry: Reuse water pollutants. Nature 2015, 528 (7580), 29-31.

(18) Verstraete, W.; Van de Caveye, P.; Diamantis, V. Maximum use of resources present in domestic "used water". Bioresour. Technol. 2009, 100 (23), 5537-5545.

(19) Guest, J. S.; Skerlos, S. J.; Barnard, J. L.; Beck, M. B.; Daigger, G. T.; Hilger, H.; Jackson, S. J.; Karvazy, K.; Kelly, L.; Macpherson,
L.; Mihelcic, J. R.; Pramanik, A.; Raskin, L.; Van Loosdrecht, M. C. M.; Yeh, D.; Love, N. G. A new planning and design paradigm to achieve sustainable resource recovery from wastewater. Environ. Sci. Technol. 2009, 43, 6126.

(20) Epstein, E. Land Application of Sewage Sludge and Biosolids. 1 ed.; CRC Press: Boca Raton, 2002.

(21) Lu, Q.; He, Z. L.; Stoffella, P. J. Land Application of Biosolids in the USA: A Review. Appl. Environ. Soil Sci. 2012, 2012, 1.

(22) Gerba, C. P.; Pepper, I. L.; Whitehead, L. F. A risk assessment of emerging pathogens of concern in the land application of biosolids. Water Sci. Technol. 2002, 46 (10), 225-230.

(23) Brooks, J. P.; Tanner, B. D.; Josephson, K. L.; Gerba, C. P.; Haas, C. N.; Pepper, I. L. A national study on the residential impact of biological aerosols from the land application of biosolids. J. Appl. Microbiol. 2005, 99 (2), 310-322.

(24) Bright, D. A.; Healey, N. Contaminant risks from biosolids land application: Contemporary organic contaminant levels in digested sewage sludge from five treatment plants in Greater Vancouver, British Columbia. Environ. Pollut. 2003, 126 (1), 39-49.

(25) Lapen, D. R.; Topp, E.; Metcalfe, C. D.; Li, H.; Edwards, M.; Gottschall, N.; Bolton, P.; Curnoe, W.; Payne, M.; Beck, A. Pharmaceutical and personal care products in tile drainage following land application of municipal biosolids. Sci. Total Environ. 2008, 399 (1-3), 50-65.

(26) Lake, D. L.; Kirk, P. W. W.; Lester, J. N. Fractionation, Characterization, and Speciation of Heavy-Metals in Sewage-Sludge and Sludge-Amended Soils - a Review. J. Environ. Qual. 1984, 13 (2), 175-183.

(27) Yetilmezsoy, K.; Sapci-Zengin, Z. Recovery of ammonium nitrogen from the effluent of UASB treating poultry manure wastewater by MAP precipitation as a slow release fertilizer. $J$. Hazard. Mater. 2009, 166 (1), 260-269.

(28) Cai, T.; Park, S. Y.; Li, Y. B. Nutrient recovery from wastewater streams by microalgae: Status and prospects. Renewable Sustainable Energy Rev. 2013, 19, 360-369.

(29) Lin, Y.; Guo, M.; Shah, N.; Stuckey, D. C. Economic and environmental evaluation of nitrogen removal and recovery methods from wastewater. Bioresour. Technol. 2016, 215, 227-238.

(30) Batstone, D. J.; Hülsen, T.; Mehta, C. M.; Keller, J. Platforms for energy and nutrient recovery from domestic wastewater: A review. Chemosphere 2015, 140, 2-11.

(31) Bilyk, K.; Bustamante, H.; Connor, M.; deBarbadillo, C.; Downing, L.; Dupont, R.; Fattah, K.; Finch, R.; Gray, D.; Harper, W. Nutrient Recovery: State of the Knowledge. Water Environ. Res. Foundation 2011, 1, 1-19.

(32) Mehta, C. M.; Khunjar, W. O.; Nguyen, V.; Tait, S.; Batstone, D. J. Technologies to Recover Nutrients from Waste Streams: A Critical Review. Crit. Rev. Environ. Sci. Technol. 2015, 45 (4), 385427.

(33) Pastor, L.; Mangin, D.; Ferrer, J.; Seco, A. Struvite formation from the supernatants of an anaerobic digestion pilot plant. Bioresour. Technol. 2010, 101 (1), 118-125.

(34) Desloover, J.; Abate Woldeyohannis, A.; Verstraete, W.; Boon, N.; Rabaey, K. Electrochemical Resource Recovery from Digestate to Prevent Ammonia Toxicity during Anaerobic Digestion. Environ. Sci. Technol. 2012, 46 (21), 12209-12216.

(35) Ippersiel, D.; Mondor, M.; Lamarche, F.; Tremblay, F.; Dubreuil, J.; Masse, L. Nitrogen potential recovery and concentration of ammonia from swine manure using electrodialysis coupled with air stripping. J. Environ. Manage. 2012, 95, S165-S169.

(36) Anastas, P. T.; Zimmerman, J. B. Design through the Twelve Principles of Green Engineering. Environ. Sci. Technol. 2003, 37 (5), $94 \mathrm{~A}-101 \mathrm{~A}$

(37) Karak, T.; Bhattacharyya, P. Human urine as a source of alternative natural fertilizer in agriculture: A flight of fancy or an achievable reality. Resour. Conserv. Recycl. 2011, 55 (4), 400-408.

(38) Larsen, T. A.; Alder, A. C.; Eggen, R. I. L.; Maurer, M.; Lienert, J. Source separation: Will we see a paradigm shift in wastewater handling? Environ. Sci. Technol. 2009, 43 (16), 6121. 
(39) Simha, P.; Ganesapillai, M. Ecological Sanitation and nutrient recovery from human urine: How far have we come? A review. Sustain. Environ. Res. 2017, 27 (3), 107-116.

(40) Gao, X. S. T.; Zheng, Y.; Sun, X.; Huang, S.; Ren, Q.; Zhang, X.; Tian, Y.; Luan, G. Practical manure handbook. In Chinese. Agricultural Publishing House: Beijing, 2002.

(41) Larsen, T. A. U.; Lienert, J. Source separation and decentralization for wastewater management. Iwa Publishing: 2013.

(42) Jönsson, H.; V, B. Adapting the nutrient content of urine and faeces in different countries using FAO and Swedish data, Proceedings of the 2nd International Symposium on ecological sanitation, 2003; pp $7-11$.

(43) Mihelcic, J. R.; Fry, L. M.; Shaw, R. Global potential of phosphorus recovery from human urine and feces. Chemosphere 2011, 84 (6), 832-839.

(44) Larsen, T. A.; Hoffmann, S.; Lüthi, C.; Truffer, B.; Maurer, M. Emerging solutions to the water challenges of an urbanizing world. Science 2016, 352 (6288), 928-933.

(45) Randall, D. G.; Naidoo, V. Urine: The liquid gold of wastewater. J. Environ. Chem. Eng. 2018, 6 (2), 2627-2635.

(46) Maurer, M.; Pronk, W.; Larsen, T. A. Treatment processes for source-separated urine. Water Res. 2006, 40 (17), 3151-3166.

(47) Başakçilardan-Kabakci, S.; İpekoğlu, A. N.; Talinli, I. Recovery of Ammonia from Human Urine by Stripping and Absorption. Environ. Eng. Sci. 2007, 24 (5), 615-624.

(48) Kabdaşlı, I.; Tünay, O.; İşlek, Ç.; Erdinç, E.; Hüskalar, S.; Tatll, M. B. Nitrogen recovery by urea hydrolysis and struvite precipitation from anthropogenic urine. Water Sci. Technol. 2006, 53 (12), 305312.

(49) Ledezma, P.; Kuntke, P.; Buisman, C. J. N.; Keller, J.; Freguia, $\mathrm{S}$. Source-separated urine opens golden opportunities for microbial electrochemical technologies. Trends Biotechnol. 2015, 33 (4), 214220.

(50) Udert, K. M.; Wächter, M. Complete nutrient recovery from source-separated urine by nitrification and distillation. Water Res. 2012, 46 (2), 453-464.

(51) Kabdaşl1, I.; Tünay, O. Nutrient recovery by struvite precipitation, ion exchange and adsorption from source-separated human urine - a review. Environ. Technol. Rev. 2018, 7 (1), 106-138.

(52) Udert, K. M.; Larsen, T. A.; Biebow, M.; Gujer, W. Urea hydrolysis and precipitation dynamics in a urine-collecting system. Water Res. 2003, 37 (11), 2571-2582.

(53) Liu, Y.; Kumar, S.; Kwag, J. H.; Ra, C. Magnesium ammonium phosphate formation, recovery and its application as valuable resources: a review. J. Chem. Technol. Biotechnol. 2013, 88 (2), 181-189.

(54) Lawson, K. W.; Lloyd, D. R. Membrane Distillation. J. Membr. Sci. 1997, 124 (1), 1-25.

(55) Alkhudhiri, A.; Darwish, N.; Hilal, N. Membrane distillation: A comprehensive review. Desalination 2012, 287, 2-18.

(56) Drioli, E.; Ali, A.; Macedonio, F. Membrane distillation: Recent developments and perspectives. Desalination 2015, 356, 56-86.

(57) Zarebska, A.; Nieto, D. R.; Christensen, K. V.; Norddahl, B. Ammonia recovery from agricultural wastes by membrane distillation: Fouling characterization and mechanism. Water Res. 2014, 56, 1-10.

(58) Qu, D.; Sun, D.; Wang, H.; Yun, Y. Experimental study of ammonia removal from water by modified direct contact membrane distillation. Desalination 2013, 326, 135-140.

(59) Duong, T.; Xie, Z.; Ng, D.; Hoang, M. Ammonia removal from aqueous solution by membrane distillation. Water Environ. J. 2012, 27 (3), 425-434.

(60) Bodell, B. R., Distillation of Saline Water Using Silicone Rubber Membrane. U.S. Patent 3,361,645A, 1968.

(61) Ahn, Y. T.; Hwang, Y. H.; Shin, H. S. Application of PTFE membrane for ammonia removal in a membrane contactor. Water Sci. Technol. 2011, 63 (12), 2944-2948.

(62) Ding, Z.; Liu, L.; Li, Z.; Ma, R.; Yang, Z. Experimental study of ammonia removal from water by membrane distillation (MD): The comparison of three configurations. J. Membr. Sci. 2006, 286 (1-2), 93-103.

(63) Kartohardjono, S.; Fermi, M. I.; Yuliusman; Elkardiana, K.; Sangaji, A. P.; Ramadhan, A. M. The Removal of Dissolved Ammonia from Wastewater through a Polypropylene Hollow Fiber Membrane Contactor. Int. J. Technol. 2015, 6 (7), 1146-1152.

(64) Lauterbock, B.; Moder, K.; Germ, T.; Fuchs, W. Impact of characteristic membrane parameters on the transfer rate of ammonia in membrane contactor application. Sep. Purif. Technol. 2013, 116, $327-334$.

(65) Lin, P. H.; Horng, R. Y.; Hsu, S. F.; Chen, S. S.; Ho, C. H., A Feasibility Study of Ammonia Recovery from Coking Wastewater by Coupled Operation of a Membrane Contactor and Membrane Distillation. Int. J. Environ. Res. Public Health 2018, 15, (3). DOI: ARTN 441441.

(66) Liu, H. Y.; Wang, J. L. Separation of ammonia from radioactive wastewater by hydrophobic membrane contactor. Prog. Nucl. Energy 2016, 86, 97-102.

(67) Lu, J.; Li, B. A.; Wang, L.; Wang, Y.; Wang, S. C. Utilization of ammonia-containing wastewater by combining membrane absorption and vacuum membrane distillation. J. Chem. Technol. Biotechnol. 2014, 89 (2), 312-321.

(68) Tun, L. L.; Jeong, D.; Jeong, S.; Cho, K.; Lee, S.; Bae, H. Dewatering of source-separated human urine for nitrogen recovery by membrane distillation. J. Membr. Sci. 2016, 512, 13-20.

(69) Xia, Q.; Yun, Y. B.; Chen, J. J.; Qu, D.; Li, C. L.; Zhu, S. W. Treatment of ammonia nitrogen wastewater by membrane distillation using PVDF membranes. Desalin. Water Treat. 2017, 61, 126-135.

(70) Xu, K. N.; Qu, D.; Zheng, M.; Guo, X. H.; Wang, C. W., Water Reduction and Nutrient Reconcentration of Hydrolyzed Urine via Direct-Contact Membrane Distillation: Ammonia Loss and Its Control. J. Environ. Eng. 2019, 145, (3). DOI: Artn 04018144 04018144.

(71) Daguerre-Martini, S.; Vanotti, M. B.; Rodriguez-Pastor, M.; Rosal, A.; Moral, R. Nitrogen recovery from wastewater using gaspermeable membranes: Impact of inorganic carbon content and natural organic matter. Water Res. 2018, 137, 201-210.

(72) Vanotti, M. B.; Dube, P. J.; Szogi, A. A.; García-González, M. C. Recovery of ammonia and phosphate minerals from swine wastewater using gas-permeable membranes. Water Res. 2017, 112, 137-146.

(73) Kuntke, P.; Zamora, P.; Saakes, M.; Buisman, C. J. N.; Hamelers, H. V. M. Gas-permeable hydrophobic tubular membranes for ammonia recovery in bio-electrochemical systems. Environ. Sci. Water Res. Technol. 2016, 2 (2), 261-265.

(74) Tarpeh, W. A.; Barazesh, J. M.; Cath, T. Y.; Nelson, K. L. Electrochemical Stripping to Recover Nitrogen from SourceSeparated Urine. Environ. Sci. Technol. 2018, 52 (3), 1453-1460.

(75) EL-Bourawi, M. S.; Khayet, M.; Ma, R.; Ding, Z.; Li, Z.; Zhang, $\mathrm{X}$. Application of vacuum membrane distillation for ammonia removal. J. Membr. Sci. 2007, 301 (1-2), 200-209.

(76) He, Q. Y.; Tu, T.; Yan, S. P.; Yang, X.; Duke, M.; Zhang, Y. L.; Zhao, S. F. Relating water vapor transfer to ammonia recovery from biogas slurry by vacuum membrane distillation. Sep. Purif. Technol. 2018, 191, 182-191.

(77) Sarbatly, R.; Chiam, C. K., Ammonia Removal from Saline Water by Direct Contact Membrane Distillation. In Sustainable Membrane Technology for Energy, Water, and Environment; Wiley: 2012; pp 309-317.

(78) Wu, C. R.; Yan, H. H.; Li, Z. G.; Lu, X. L. Ammonia recovery from high concentration wastewater of soda ash industry with membrane distillation process. Desalin. Water Treat. 2016, 57 (15), $6792-6800$.

(79) Xie, Z. L.; Duong, T.; Hoang, M.; Nguyen, C.; Bolto, B. Ammonia removal by sweep gas membrane distillation. Water Res. 2009, 43 (6), 1693-1699.

(80) Liu, Q. L.; Liu, C. H.; Zhao, L.; Ma, W. C.; Liu, H. L.; Ma, J. Integrated forward osmosis-membrane distillation process for human urine treatment. Water Res. 2016, 91, 45-54. 
(81) Rittner, D., Bailey, R. A., Clausius-Clapeyron equation. In Facts on File science encyclopedia: Encyclopedia of chemistry (2nd ed.). 2016. (82) Wang, P.; Chung, T. S. Recent advances in membrane distillation processes: Membrane development, configuration design and application exploring. J. Membr. Sci. 2015, 474, 39-56.

(83) Rezakazemi, M.; Shirazian, S.; Ashrafizadeh, S. N. Simulation of ammonia removal from industrial wastewater streams by means of a hollow-fiber membrane contactor. Desalination 2012, 285, 383-392.

(84) El-Bourawi, M. S.; Ding, Z.; Ma, R.; Khayet, M. A framework for better understanding membrane distillation separation process. $J$. Membr. Sci. 2006, 285 (1-2), 4-29.

(85) Smith, J.M. Introduction to Chemical Engineering Thermodynamics. 2005, 357-358.

(86) Bates, R. G.; Pinching, G. D. Acidic dissociation constant of ammonium ion at 0 to $50 \mathrm{C}$, and the base strength of ammonia. J. Res. Natl. Bur. Stand. 1949, 42 (5), 419-430.

(87) Bolleter, W. T.; Bushman, C. J.; Tidwell, P. W. Spectrophotometric Determination of Ammonia as Indophenol. Anal. Chem. 1961, 33 (4), 592-594.

(88) Schofield, R. W.; Fane, A. G.; Fell, C. J. D. Heat and mass transfer in membrane distillation. J. Membr. Sci. 1987, 33 (3), 299313.

(89) Fane, A. G.; Schofield, R. W.; Fell, C. J. D. The efficient use of energy in membrane distillation. Desalination 1987, 64, 231-243.

(90) Khayet, M. Membranes and theoretical modeling of membrane distillation: A review. Adv. Colloid Interface Sci. 2011, 164 (1-2), 5688.

(91) Zhu, Z.; Hao, Z.; Shen, Z.; Chen, J. Modified modeling of the effect of $\mathrm{pH}$ and viscosity on the mass transfer in hydrophobic hollow fiber membrane contactors. J. Membr. Sci. 2005, 250 (1-2), 269-276.

(92) Deshmukh, A.; Lee, J. Membrane desalination performance governed by molecular reflection at the liquid-vapor interface. Int. J. Heat Mass Transfer 2019, 140, 1006-1022.

(93) Shi, Q.; Davidovits, P.; Jayne, J. T.; Worsnop, D. R.; Kolb, C. E. Uptake of gas-phase ammonia. 1. Uptake by aqueous surfaces as a function of pH. J. Phys. Chem. A 1999, 103 (44), 8812-8823.

(94) Eames, I. W.; Marr, N. J.; Sabir, H. The evaporation coefficient of water: A review. Int. J. Heat Mass Transfer 1997, 40 (12), 29632973.

(95) Marek, R.; Straub, J. Analysis of the evaporation coefficient and the condensation coefficient of water. Int. J. Heat Mass Transfer 2001, 44 (1), 39-53.

(96) Kerkhof, P. J. A. M. A modified Maxwell-Stefan model for transport through inert membranes: The binary friction model. Chem. Eng. J. 1996, 64 (3), 319-343.

(97) Krishna, R.; Wesselingh, J. A. Review article number 50 - The Maxwell-Stefan approach to mass transfer. Chem. Eng. Sci. 1997, 52 (6), 861-911.

(98) Cussler, E., Multicomponent Diffusion. In Multicomponent Diffusion; Elsevier: 2013; p 39.

(99) Lin, S.; Yip, N. Y.; Elimelech, M. Direct contact membrane distillation with heat recovery: Thermodynamic insights from module scale modeling. J. Membr. Sci. 2014, 453, 498-515.

(100) NIST Chemistry Webook, SRD 69: Ammonia. https:// webbook.nist.gov/cgi/cbook.cgi? ID =7664-41-7 (Accessed on 02/20/ 2019).

(101) NIST Chemistry Webook, SRD 69: Water. https://webbook. nist.gov/cgi/cbook.cgi? ID=C7732185 (Accessed on 02/20/2019).

(102) Vanneste, J.; Bush, J. A.; Hickenbottom, K. L.; Marks, C. A.; Jassby, D.; Turchi, C. S.; Cath, T. Y. Novel thermal efficiency-based model for determination of thermal conductivity of membrane distillation membranes. J. Membr. Sci. 2018, 548, 298-308.

(103) Leitch, M. E.; Lowry, G. V.; Mauter, M. S. Characterizing convective heat transfer coefficients in membrane distillation cassettes. J. Membr. Sci. 2017, 538, 108-121.

(104) Kalogirou, S. A. Solar thermal collectors and applications. Prog. Energy Combust. Sci. 2004, 30 (3), 231-295.
(105) Wong, L. T.; Mui, K. W.; Guan, Y. Shower water heat recovery in high-rise residential buildings of Hong Kong. Appl. Energy 2010, 87 (2), 703-709.

(106) Liu, L. B.; Fu, L.; Jiang, Y. Application of an exhaust heat recovery system for domestic hot water. Energy 2010, 35 (3), 14761481.

(107) McFeeters, R., Reuse of fermentation brines in the cucumber pickling industry. In Environmental Protection Agency, O. o. R. a. D., Industrial Environmental Research Laboratory, Ed. 1978; Vol. 1.

(108) Romero Barranco, C; Brenes Balbuena, M; Garcia Garc1a, P; Garrido Fernandez, A Management of spent brines or osmotic solutions. J. Food Eng. 2001, 49 (2), 237-246.

(109) Kammen, D. M.; Sunter, D. A. City-integrated renewable energy for urban sustainability. Science 2016, 352 (6288), 922-8.

(110) World Health Organization. Progress on sanitation and drinking water: 2015 update and MDG assessment. In 2015.

(111) Zhang, L.; De Schryver, P.; De Gusseme, B.; De Muynck, W.; Boon, N.; Verstraete, W. Chemical and biological technologies for hydrogen sulfide emission control in sewer systems: a review. Water Res. 2008, 42 (1-2), 1-12. 